\title{
Educating prospective entrepreneurship researchers: the case of a summer school as a learning community
}

\author{
Alexander Chepurenko ${ }^{2}\left(\mathbb{D} \cdot\right.$ Olga Belousova $^{1} \cdot$ Aard Groen $^{1}$
}

Received: 22 June 2020 / Revised: 6 September 2020 / Accepted: 13 September 2020 /

Published online: 21 September 2020

(c) Springer Nature Singapore Pte Ltd. 2020

\begin{abstract}
The paper describes the case of the European entrepreneurship summer school (EESS) supported by a consortium of universities from different countries. The paper develops a set of theoretical propositions and practical recommendations for creating a learning community and space around a summer school activity in the context of a larger ecosystem encouraging students to choose a career in the respective area. The core elements building the innovativeness of the concept of this educational initiative are analyzed. First, it is the complementarity of expertise which shapes a teachers' learning community'. Second, it is the active involvement of students achieved through preselection of motivated participants, coaching, and an individual and group work. Third, it is a creation of a safety feeling among participants to increase the mutual trust and intensive interactions among students. Forth, it is the co-opetition among students collaborating but also competing with the group-project presentations. Fifth, it is the pre-school preparation of students to achieve a minimal level of common knowledge of related concepts and techniques. The limitations of the EESS model are: (1) the international team of teachers, (2) the geographical dispersion which negatively contributes to the students' pre-school learning community, (3) the volunteering activity of the organizers and teaching staff, which is limited by their main workload, (4) the financial model which does not allow to become sustainable without a support of the participating universities.
\end{abstract}

Keywords Entrepreneurship education · Summer school · Case study · Learning community

Alexander Chepurenko

achepurenko@hse.ru

1 University College Groningen, Kadijk 4, 9747 AT Groningen, The Netherlands

2 National Research University Higher School of Economics, 20, Myasnitskaya st, Moscow,

Russia 100990 


\section{Introduction}

The past decade has been called "a golden era" for entrepreneurship research for having "emerged as one of the most vital, dynamic, and relevant" periods in the social sciences (Wiklund et al. 2011: 1). Entrepreneurship education can be designed in different ways which differ according to Pittaway and Edwards (2012) as teaching "about", "for", and "through." Most entrepreneurship education has been found to be of the "about" approach, which does not engage the students in activities and projects (Pittaway and Edwards 2012; Nielsen and Stovang 2015). It has also been stressed in the literature that entrepreneurship education should be reconfigured from being teacher-centered to student-centered education (Daniel 2016; Robinson et al. 2016).

Summer schools, being self-sufficient, project-oriented educational modules, offer a model of combination of pro-entrepreneurial activity of teachers and students that can be implemented into the academic core of colleges and universities (Doane and Pusser 2005). In this paper, we describe the practice of an international summer school combining at least teaching "about" and teaching "through" when engaging students in entrepreneurship research. Educating students "about" the context, history, methods, and theories of entrepreneurship is necessary to help them to get acquainted with the accumulated knowledge about entrepreneurship in the mainstream literature. It happens in a more intensive way when being done "through" own engagement in project work before and during the educational process, as it is realized in the concept of this summer school. Experiential approaches in entrepreneurship education can include experiencing entrepreneurship through addressing a real-life challenge by conducting research about it with the aim not only to understand it, but also develop a solution for it. This enables students to properly contextualize the research findings and eventually engage with the field (Dean et al. 2007; Mudambi et al. 2012; Welter 2011; Wiklund et al. 2011; Zahra 2007). Hence, combining teaching "about" and teaching "through" becomes an innovative and effective way of pedagogy for entrepreneurial education (Higgins et al. 2013; Nabi et al. 2017).

Albeit summer schools became an inevitable part of universities' educational activities in the last 40 years, literature on summer schools as a specific kind of educational modules is rather limited. Mainly, summer schools are viewed by universities as an addition to academic programs enabling students the access to out-of-curriculum opportunities. In spite of the fact that often a lack of funding opportunities for enrolled students might lower their interest in summer schools, many students are recognizing summer schools as an opportunity to complete courses in their major or minor, taking courses that they were unable to visit in the academic year (Kretovics et al. 2005). In addition, students can concentrate on solely one subject at a summer school; therefore, the outcomes may be quite encouraging (Daniel 2000). Summer schools are often used as remedial instruments that target students with weaker performance and offer them a possibility to catch up during summer (Stanat et al. 2012). 
Studies, however, have not yet specifically focused on summer schools that go beyond the established educational program and select students interested in short and comprehensive advanced educational modules. In this paper, we report the experience of an international, research-focused "Exploring Entrepreneurship" Summer School (EESS), existing since 2009. We analyze it from the perspective of creating learning communities of students and teachers (DuFour 2004; Wenger 1998) which lead to the development of a learning space (Kolb and Kolb 2005). We explore the following research questions: What are the core methodic findings of a research summer school as a learning community and space? Which problems and limitations can such project face and whether/how these constraints can be circumvented?

Based on our analysis, we develop a set of theoretical propositions and practical recommendations for creating a learning community and space around such a summer school activity in the context of a larger ecosystem of supporting students and leading them to choose a career in entrepreneurship research.

\section{"Exploring Entrepreneurship" Summer School as a case of learning communities of students and teachers}

\section{The history}

In 2020, the EESS in its current version should celebrate its tenth edition, but was postponed to 2021 in the context of the COVID-19 pandemic. However, the first launch of the summer school based on the principles explained below was made in 2009. Thus, it shows a certain level of sustainability, both as regards the teaching community engagement and interest of students, and therefore is worth to be presented as a case of a good educational practice in Entrepreneurship research. Over these years, it provided useful insights into the theories and research methods in entrepreneurship for more than 250 students from ca. 40 countries (predominantly Dutch, Russian, British, German, Chinese students as well as students from SouthEastern Asian nations, Latvia, Turkey, etc.). Generally, the participants differ in age (from 18 to 27), level of education (BA and MA, exceptionally also $\mathrm{PhD}$ students), area of education (mostly Management and Engineering, often also Economics, Sociology, Political Science, Psychology, sometimes Law, Cultural Studies, Media etc.). Hence, each summer school is a platform to mix experience of students with very different educational background and social experience.

The school was from the very beginning designed as a multi-element summer learning program (Terzian et al. 2009) that integrates experiential and collaborative approaches to learning (Groen et al. 2006; Pittaway and Cope 2007) to increase students' motivation, interpersonal, leadership and skills for entrepreneurship research.

The EESS's concept has developed gradually over several years. To identify the main stages of the EESS development (Table 1), we follow Fayolle et al. (2006) and analyze the EESS's content from the perspective of its institutional setting (internal culture, dedicated structures, resources, mechanisms, and institutional strategy toward the subject taught), audience (basic discipline of students, their age, nationality, and educational background), type of program (e.g., training- or 


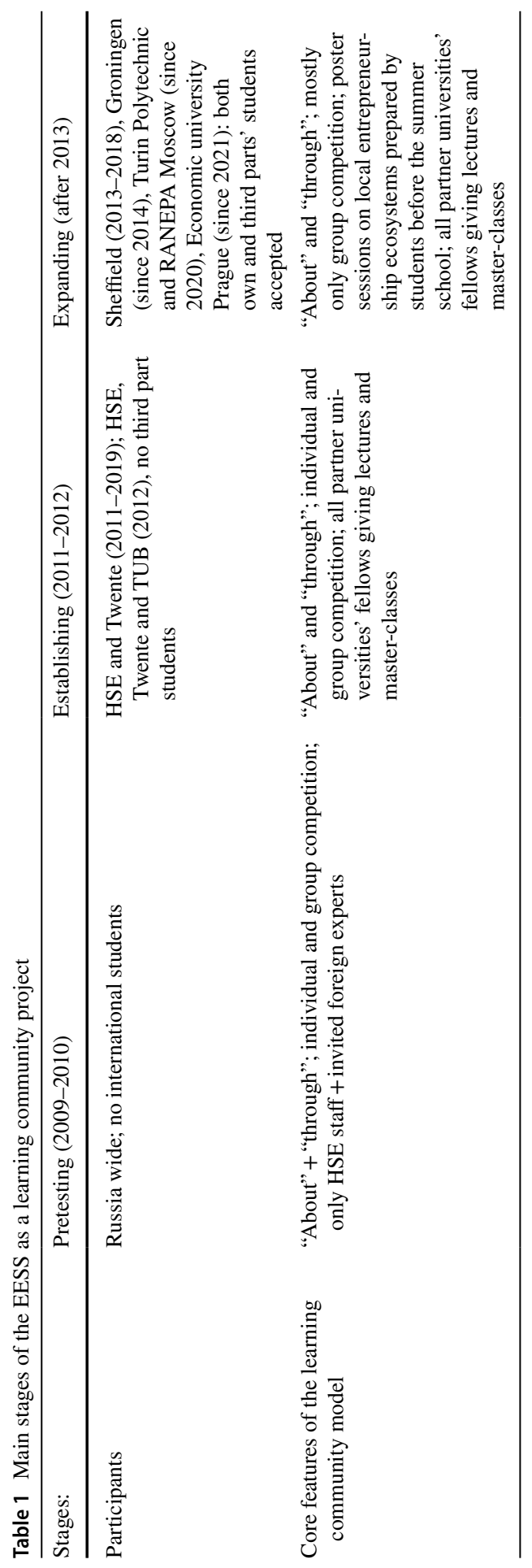


education-oriented), program objectives (e.g., pedagogical, social, or economic), program contents, and, finally, teaching approaches and methods. Each of the EESS's development periods is marked by a different institutional setup and audience, while the general structure and the teaching approaches were intentionally kept stable. As a result, three following stages of the project development can be figured out: pretesting, establishing and expansion.

This general structure embraces a combination of students' individual and groupresearch before and during the summer school; standard lectures of the partner universities' fellows and master-classes with visiting practitioners' and entrepreneurship institutions; expertise and contextual specific of participating universities' teams; entrepreneurship research focusing and cultural experience in the region of EESS location.

The first two summer school editions $(2009,2010)$ were organized for students from Russian universities on the basis of the National Research University Higher School of Economics, Moscow (HSE). They were held in Russian, except for a number of guest lectures by professors invited from abroad. Also, most of the reading material was provided in English and strongly focused on the 'Global Entrepreneurship Monitor' (GEM) concept and evidence. The participating students, 30 to 35 annually, were chosen among applicants from a variety of Russian universities and different faculties and education levels (bachelor's, master's, or PhD). After 2 years, the organizers decided to seek international partners in order to develop the school and make it more open, diverse, and challenging also for international students.

In 2011, the University of Twente's Netherlands Institute for Knowledge Intensive Entrepreneurship (NIKOS) became a partner. The EESS 2011 was bilateral and consisted of one week of classes and visits in the Netherlands (Enschede) and one week in Russia (Moscow). While students enjoyed it, this design was a logistical challenge and required a very detailed planning. Regarding the audience, it comprised HSE and University of Twente groups (10 students each) and was not open to third parties.

Since 2012 the EESS began to transform into a European summer school. First, the Technical University of Berlin joined the cooperation in 2012 and was then followed by the University of Sheffield in 2013 and the University of Groningen in 2014.

During this period, the EESS rotated between universities, finding a new home every year and allowing the partners to learn from each other's organizational routines and best practices. Each university's similarities and diversities in the ecosystems of entrepreneurship support were integrated into the design and topic of each EESS edition.

The students came from diverse educational backgrounds (e.g., management, economics, sociology, informatics, engineering, etc.), as well as different educational levels, spanning from first-year bachelor's degree students to early-stage PhDs. In this period, the school opened up to third-party applicants. Along with adding a diverse student group from the University of Sheffield, it resulted in a very international set of participants.

In some recent years, three new partners from Italy (Politecnico, Turin), Czech Republic (Economic University, Prague) and Russia (Russian Academy on National 
Economy and Public Administration, Moscow) have joined the consortium. Thus, the international character of the EESS is becoming stronger.

\section{Objectives, contents, and teaching approaches}

Although the school's theme changes every year, the EESS's objectives and teaching approaches have remained similar throughout all its editions: They revolve around entrepreneurship research and its link to societal problems.

Over the years, however, the school's various structural characteristics, such as type of tasks, discretion of students, and evaluation have been manipulated to enhance students' motivation for learning and academic performance (Debnath et al. 2007). The following sections explain how these elements were changing and how they influenced the school's outcomes.

Though the EESS is finding a new home each year, all partner universities are actively involved. Their representatives frequently interact throughout the year and contribute by recruiting students, choosing topics, and developing the EESS's program. This program consists of four learning components: (a) standard lectures (in theoretical aspects of entrepreneurship research) and master-classes (in research methods and techniques); (b) onsite visits and meetings with local actors (entrepreneurs, business park managers and residents, CEOs etc.); (c) self-preparation of small-scale research projects in mixed student teams; (d) cultural program to collect informal impressions of people and city of the EESS current residence (every year changing to another participating university's city). Besides, pre-school self-preparation required the students to read a pre-defined set of scientific papers and engage in a group-research assignment.

Lectures and master-classes aimed to provide comprehensive and thought-provoking insights into the multidisciplinary field of entrepreneurship research based on recent advances in entrepreneurship theory. Visits to active members of local entrepreneurial ecosystems, such as entrepreneurs, business support institutions, and investors, aim to increase students' empirical knowledge about the process of business venturing, the roles of the main actors, their ideas and interests, and the variety of institutional and societal contexts. The project work should enable students not only to realize the obtained knowledge in entrepreneurship theory bit also to master a desk research project and to foster soft skills in team building, leadership, communicating etc.

Every year, good elements are being retained, improvements suggested, and local adaptations made. The new staff members are required to participate in one of the schools before becoming active in organizing the EESS to allow a better preservation of the school's idea, quality, and promise. Therefore, we can characterize the EESS as a learning community due to the complementarity of expertise, multiplexity of relationships, and similar institutional development of the partners.

Complementarity of the theoretical and research approaches toward entrepreneurship has proved to be instrumental in preparing the EESS. Among the current core partners, the HSE team is stronger in macro-quantitative cross-country research of early entrepreneurial activity. The team from the University of Sheffield works from 
the position of institutional theory. The University of Twente's team-works with micro/mezzo data on high-tech entrepreneurs highlighting social system aspects of entrepreneurial action. Finally, the team from the University of Groningen provides expertise on social and corporate entrepreneurship, as well as process research methods. Such mutual complementarity makes synergetic results possible (Leahey and Reikowsky 2008) and gives this community the coherence and profile to be a community of practice (Wenger 1998).

These frequent and complementary interactions are further reinforced by multiplex collaborations (Feld 1981). Multiplexity characterizes the degree to which two participants are linked through multiple relationships (Burt and Schott 1985). Three of the partners are involved in joint research projects; two co-develop educational programs; the Dutch partner universities are forming a strategic alliance in entrepreneurial education and support; and all partners meet regularly at conferences. Such a multiplexity increases mutual investment in the relationships, as it was already shown in the literature (Feld 1981).

The learning process is further facilitated by similarities in the institutional setting of the universities and their ecosystems. Each of the partner universities is on the way to become "entrepreneurial university" (Clark 1998), having an established entrepreneurship and innovation infrastructure, including entrepreneurship courses, business incubators and knowledge transfer units. From the alliance literature, we know that similarity in the approaches, social capital, and status is among the preconditions for fruitful cooperation (Chung et al. 2000; Rothaermel and Boeker 2008; Wang and Zajac 2007). At the same time, the entrepreneurial ecosystems' organizational principles, sizes, and structures vary: from a small and cohesive system in Groningen to a very diverse and complex system in HSE Moscow. This diversity reduces potential redundancy and enables the widening of experience of students and teachers participating in the summer school.

We also recognized a limiting factor: the spatial fragmentation of work across different countries, which limits communication and makes the interaction less immediate and intense (Cox 2005). This limitation is partially counterbalanced by the shared basic principles and ideas, and the stable routines in organization of EESS, which partly reduce the costs of virtual cooperation between the partners. But with every new partner's joining the consortium, the main principles and design of the EESS need to be discussed again.

Wenger et al. (2002b) highlight the importance of facilitating contacts between individuals within the community of practice. While coaching and facilitating are also possible in a virtual design, it is easier to work with student groups in person. Also, given that the essence of the assignment was to experience research and to gain a better understanding of the local environment for entrepreneurship, the students were given the discretion to take ownership of their projects and customize the learning process to reflect their personal interests and competencies. These factors are known to contribute to better learning outcomes (Lengnick-Hall and Sanders 1997), and they appeared instrumental in our case, too.

At the beginning, we used to shape mixed groups of students before the EESS (from 2011 until 2014). In this design, pre-school assignment groups functioned as virtual groups. Virtual designs work well because students have intrinsic motivation 
for the topic, which makes their contributions more thoughtful and increases the quality of the discussions and learning. Also, in such groups shy students are less reluctant to participate in communications, and dominant students have less chance to monopolize the "floor" (Arbaugh 2000; Brower 2003; Poole 2000). The most common objection to distance learning is that students feel isolated and dissatisfied with the delivery because of a lack of interaction (Clark 2001; Eastman and Swift 2001).

During the summer, students were to formulate their standpoint, do preliminary research, and gather relevant information using chats or the common Facebook group etc. On site they analyzed, discussed, and polished their findings to present them at the school's final session. In our experience, geographical dispersion constantly outweighed the benefits of the virtual design, possibly because of the lack of a tangible deliverable or because of varying study schedules. As such, students did not have the moral obligation to work on the assignment before actually coming to school; also, as they came from different countries, study years and programs, and had their own deadlines and vacation terms, it complicated planning and influenced the intensity of preparatory work on the assignment. Therefore, in 2015 a decision was made to postpone the formation of mixed groups on the summer school week itself; making the process of team building and producing of the final group presentation much shorter and intensive, it thus provokes students from different universities, languages and specializations wishing to perform best to work hard over the evenings to achieve the result. On that way, a very intensive mutual exchange and learning are achieved.

\section{EESS week as a learning community and space}

Scholars have addressed the role of a community in learning in multiple ways. Some focus on "professional learning communities" (Cheng and Wu 2016; DuFour 2004; Stoll et al. 2006; Vescio et al. 2008). Others have focused on "communities of practice" (Sorenson and Milbrandt 2015; Wenger et al. 2002a). These two approaches share basic tenets. They both aim for learning as professional development and creation of knowledge, emphasize the collaboration and sharing, acknowledge the importance of supportive, open, and non-threatening community atmosphere, and consider participant autonomy and empowerment as one of the ultimate goals of development (Cheng and $\mathrm{Wu} 2016$ ). Although there are differences between the two approaches (Lee and Shaari 2012; Sorenson and Milbrandt 2015), within the context of the commonality mentioned above, we use the two terms interchangeably because the EESS is combining the theoretical learning ("professional") with the onsite visits to entrepreneurship ecosystem basic institutions in the respective regions and master-classes and debates with practitioners ("communities of practice").

Learning arises from participation in a community (Howorth et al. 2012) and relies on reasoned argumentation, critical analysis, and collective reflection (Kumpulainen and Rajala (2017); Mercer and Howe 2012). Therefore, we argue that (summer) learning activities should aim to build a community of teachers and students and provide a space for discussion and reflection. 
The learning community's other layer is the students' learning community, which is shaped using three basic elements: (1) selection of motivated participants, (2) team building of local students, (3) building of mixed student teams.

The shaping of the learning community of students begins at the pre-school stage. Prospective participants have to fill in a template while objectifying the reason of their personal interest to the theme and eventually already mastered essays, year works etc. on the topics related to the entrepreneurship research area. Such filtering helps to select only those who are assumed to really be interested merely in hard working than in the cultural program and related activities. The fee for participation can be considered as an additional barrier to "leisure participation." Thus, participants know they are in a community of like-minded people who are serious about the topic and are not attending for the sake of tourism (only). This does not always work as intended and, especially in attractive destinations (e.g. Thessaloniki in 2016), there are a few students who are not fully committed to the school; with a good group size; however, their influence shrinks.

Second, students of partner universities are requested to jointly prepare and be ready to present during the EESS a poster on either the local entrepreneurship ecosystem or the EE of the own university. Our second design has been in use since 2015. Here the homework is done in teams from the same university and centers on the city's or region's entrepreneurial ecosystem. Local teachers serve as coaches. Already the first pilot with "local" design showed that students were much more involved in the pre-school interactions and relatively more engaged in the summer school's agenda as they could link the discussions to the pre-school assignment and their home city experience.

When working on the poster, students, first, are discovering and discussing the structure, strong and weak points of the local entrepreneurship ecosystem, and thus become practically engaged into exploration of the challenging concept of the entrepreneurship ecosystem (Acs et al. 2014; Gustafsson and Ritala 2018 etc.). Moreover, they become acquainted and are learning by doing in an intensive exchange of knowledge and skills (usually, there are students of the same university but from different fields and different levels of study). Local teaching staff members do facilitate the local teams at the initial stage and provide consultancy and advice on the latter stages of the local entrepreneurship ecosystem poster mastering. Third part students are advised to master the poster individually.

During the EESS, the presentations of the posters help to explain to the students the variety of forms and structures of local EE and thus to make evident that the entrepreneurship theory has to do with different entrepreneurial framework conditions, cultures, etc.

As a third instrument, selected students are introduced to each other some months before the EESS starts. Then, a full list of participants and preparatory materials is published in a common Dropbox folder, and students are invited to collaborate on it. They also receive an invitation to join an EESS Facebook group-one community uniting alumni from all the EESS editions. We have tested two different designs for the pre-school home assignment for mixed groups: working in international "virtual" groups and in "local" university groups. 
Learning space is a concept offered by Kolb and Kolb (2005) and inspired by the work of Kurt Lewin. Learning spaces appear when classroom conditions encourage individuals to drop barriers and openly share feelings, thoughts, and experiences, while collaborating to apply course concepts (Sorenson and Milbrandt 2015). For a learning space to exist, the classroom should provide a sense of trust and psychological safety, regular interactions among group members, and respect and shared seriousness of purpose (Sorenson and Milbrandt 2015).

Psychological safety is needed for people to overcome their learning anxieties and engage openly in the learning process (Edmondson 1999, 2004). Trust is one of its major antecedents (Edmondson 1999, 2004; Howorth et al. 2012). When members of the learning group trust each other, individuals feel more comfortable exchanging their thoughts, experiences, uncertainties, or lack of understanding openly, which engenders social learning. "Summer" appeared to be one of the important factors increasing psychological safety in the EESS. The relaxing atmosphere of being in a different city with different people and outside their normal context was mentioned positively in the student feedback.

By allowing mixed groups with varying levels of entrepreneurship knowledge, the EESS pays attention to the ideas of the social-cognitive theories that emphasize the role of collaboration with others in the production of knowledge and understanding (Bechard and Gregoire 2005). Here, we actively engage the principle of peer (as opposed to teacher-student) coaching. It was demonstrated that students perceive a teacher's knowledge of science as indicative of membership to an inaccessible elite group because teachers often engage in "front-stage performances" (Goffman 1959) and hide their struggles with the material (Olitsky 2007). Peers, on the other hand, are more likely to identify with ambiguity and lack of certainty (Olitsky 2007) and to provide the necessary knowledge and comfort (Bryant 2005; Eby 1997; Ensher et al. 2001), which helps to establish trust in the group. The power of peer influence has long been noted in psychology (Bennis et al. 1973), coaching (DeMarco and McCullick 1997), and teaching climate (Ruzek et al. 2016) literatures. Similarly, EESS participants highlighted "positive environment," "diverse other participants," and even "kindness" in their evaluations.

The EESS's first 2 days are devoted to accommodating in the host city, team building, and poster presentations, so participants get to know each other. Networking behaviors, among peers or between students and professors, facilitate learning and knowledge acquisition (Hwang et al. 2004; Leeman and Whymark 2001; Sonnenberg 1990).

To further increase communications, familiarity, and integration among the participants, mixed groups of students are formed. One group usually comprises four to six people. These groups work intensively throughout the week to prepare a final project. They feature a diversity of areas of studies (e.g. engineering, business, or arts), levels of education of participants (BA, MA, MSc, MBA), and social experiences. This diversity provides significant added value to cross-cultural (highlighting diversity) and intercultural and interdisciplinary (implying interaction) understanding (Gu et al. 2010). As such, in 2015, there were 19 nationalities among 38 participants, and in 2017, 11 nationalities among 37 participants. As we could observe, if 
no special group dominated, interactions were more fluid and demonstrated mutual interest.

Kirkman et al. (2013) have reported a similar J-shaped relationship between nationality diversity and performance, meaning that the highest levels of performance occurred in communities with a very high level of nationality diversity. They explained it with two competing processes: social categorization (when people sort one another into categories based on demographics and act according to these perceived categories) and information perspective (which suggests that diverse individuals bring different perspectives to tasks, enriching decision quality and collaborative performance). The positive effects of diversity depend on the balance between these underlying processes (Kirkman et al. 2013) and emerge when social categorization effects are minimized, and information effects are more pronounced.

While running the EESS, we observed that more diverse groups (the 2013 and 2015 editions) bonded more easily and showed a lot of mutual interest and appreciation. In their feedback, students mentioned "group size," "interactions," and "strongly diverse pool of participants" as positive factors to keep for future editions. In smaller editions (2012, 2014, 2016, 2018 and 2019), we observed that most of the students preferred to stick to their national groups and did not develop deep relations within their assignment teams.

Diversity of students' backgrounds and study years can potentially minimize social categorization and contribute to more social interaction and contact in the school. However, they can also lead to deterioration in the quality of the outcomes. To avoid it, increased diversity among students should be coupled with a matching variety of teaching approaches (Lengnick-Hall and Sanders 1997). Therefore, EESS combines group and individual work, lectures, debates, and workshops, as well as guest lectures and site visits in a short but intensive program. In their open-ended feedback, students usually mention the excellent integration of reading-homeworklectures and do positively characterize each of the forms of activities separately.

One of the bigger problems in running a summer school is achieving a balance between "summer" and "school": On the one hand, the summer activity should be enjoyable and provide a possibility to rest from the stress of the study year; on the other hand, "school" activity should cater to learning objectives.

Ensuring the participants have a serious attitude would be impossible without their own intrinsic motivation for learning (Deci and Ryan 1985; Vedder-Weiss and Fortus 2012). The EESS has always related its yearly theme to acute problems or problems related to the context of the school venue and the European agenda (Kenworthy-U'Ren et al. 2005). For example, the themes have included topics such as "entrepreneurship and crisis" after the 2009 financial crisis, "social entrepreneurship" when the school came to the earthquake-affected provinces of the Northern Netherlands, and "immigrant entrepreneurship" in 2016 when the school took place in Greece during the Syrian refugee crisis. Societal engagement and the topic's relevance to the students are often the way the final presentation groups are formed.

Additionally, the EESS tries to implement the co-opetition principle during the summer school. To foster collaboration, team-work has a significant impact on the final grading. The final group presentations are evaluated by the international teaching staff, but the "fans" (students' audience) have also the possibility to raise 
questions, comments and thus to influence the teachers' voting for the best group. Besides, until 2015, the students were been graded individually each day for their activity and intelligence to receive a cumulated scoring of all participants over the week and to celebrate the best three participants. This approach has pros and cons. The grading for individual work requires that teachers constantly be alert and able to remember good questions and the names of the students who asked them, which is often a challenge. It also requires consistency across teachers. The lack of transparency in individual grading had been a frequent object of criticism by the student participants; therefore, in 2016, we tested a non-grading approach. Unfortunately, students showed less engagement and activity than before. Therefore, we moved back to the grading of students in recent years.

\section{Conclusion and implications}

The EESS provides a good example of an out-of-curriculum educational module to increase students' knowledge in entrepreneurship theory and related research methods (educating "about"), as well as a platform to share learning materials and approaches among interested universities. It embraces the educational practices of an action-oriented approach (educating 'through') and presents the entrepreneurship research domain as context-dependent and experiential.

The conceptual model of the EESS as it grew over the years of conducting it is depicted in Fig. 1.

This model describes the factors that support the learning community of teachers, such as complementarity of expertise, equal institutional development, intensity of collaborations, and routine procedures. It further highlights the factors that we noticed support a learning community of students, such as pre-school homework with a deliverable, coaching by the local teachers, and a strong diversity of nationalities and educational backgrounds. We further found that the informal summer atmosphere and peer coaching help establish mutual trust among students, intensive academic and social program based on group work along with nationality diverse backgrounds contribute to mutual interest, interactions and bonding. At the same time, strong intrinsic motivation for the topic of the school, as well as preselection, contributes to a serious treatment of the topic and of other participants. For students, a specific added value of the school is that it demonstrates the context-dependence of entrepreneurial activity and performance, and provides a better orientation to the variety of methods and techniques used in entrepreneurship research. This allows them to better engage with the material in the rest of the entrepreneurship education curriculum and enhances student team-work through a cross-cultural experience (supporting the arguments of Gu et al. 2010).

Owing to most students' early phase of development, we still have to see how many of the students will eventually start an entrepreneurship research career; a stable group in Facebook helps to maintain the contact to alumni and to get insights into their career development after the summer school. To date, we know about seven cases of former participants at the EESS entering graduate schools to work on entrepreneurship-related topics, at least five of them have already 


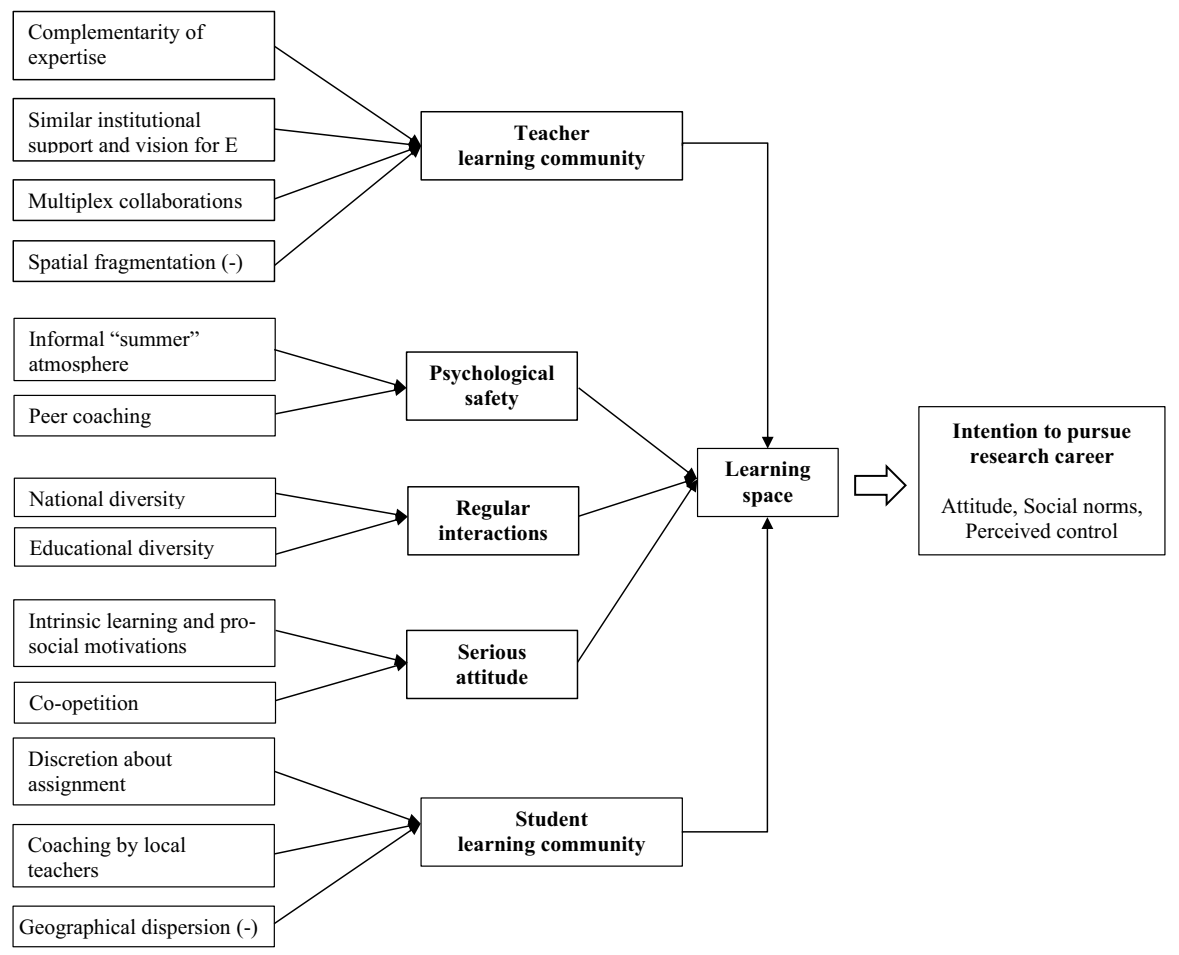

Fig. 1 The methodic concept of the EESS

graduated from prestigious universities and have academic careers. Some former participants have started to work for different national entrepreneurship support institutions. Some of them were asked to assess the specifics of the EESS and its role in their careers.

Participant AF, who as doctoral student took part in the first summer school as a teaching assistant and is now Assistant Professor in Entrepreneurship at one of the Dutch universities, mentioned that: "The uniqueness of EESS, as I see it, is that it brings together students from different disciplines, and different levels of study (BSc, $\mathrm{MSc}$, early $\mathrm{PhD}$ ) to do research on entrepreneurship. I definitely gained more knowledge about the different entrepreneurial ecosystems in different locations in Europe through the poster presentations. EESS helped me to grow my network: some of the participants are currently doctoral students or entrepreneurship researchers."

Italian alumni, GS, who took part in two EESS selections, pointed out "the opportunity to work in a multicultural team of students from different levels of education and background on a common research topic. I also liked the informal environment that the teachers created. During the EESS you have the opportunity to learn about a different entrepreneurial ecosystem. For instance, we visited a Science Park in Russia, the Skolkovo Innovation Center. It was a very interesting experience. [...] I have improved my knowledge of entrepreneurship research and social entrepreneurship. I have better understood how universities and students can collaborate 
with corporations thanks to the onsite visit to local entrepreneurs and managers of the entrepreneurial ecosystem.

Since we worked in a multicultural and interdisciplinary team, I have improved my team-work and time management, as I had to work during the summer "holidays".

Lastly, I became more pro-active thanks to the EESS. It helped me to improve my international network of researchers and professors of entrepreneurship. I'm working with them in order to bring the EESS to Politecnico di Torino since it was a great experience for me, and I'd also like other students from Politecnico di Torino to have this opportunity. I'm still in contact with several students of EESS."

Russian participant, JP, stressed that: "the school format supposes the team-work of researchers from different countries with a common interest-entrepreneurship. We discussed possibilities of conducting joint research with foreign colleagues. EESS gives an opportunity to communicate with leading international academics and to discuss your own research.

I discovered a strong dependence of entrepreneurship development on the national context. Secondly, I started to research entrepreneurship on the micro and macro levels using new approaches. I have also discovered new fields of research which I am currently following.

The summer school influenced my career development. Currently I am employed at the Department of entrepreneurship development of the Russian Ministry of Economic Development. One of the main rules for me is to keep up current research of entrepreneurship and apply it in practice... I am inspired by examples of school participants who just had discussed the research framework two years ago and today are making publications in scientific journals."

The core lessons of the EESS as a learning community and space which could be used by other similar initiatives are as follows. First, it is the complementarity of expertise which shapes a teachers' learning community and a strong synergetic effect which brings participant several benefits and supports the evidence regarding the role of complementarity, similar status and social capital in alliance formation (Chung et al. 2000). Second, it is the active involvement of students into this learning community achieved through preselection of participants interested in the subject, coaching, an individual and group work before and during the summer school, which strengthens their engagement and their learning outcomes. Third, it is a creation of a safety feeling among participants (due to in-group work, peer coaching, joint visits and cultural events at the periphery of the EESS) which increases the mutual trust and helps establishing intensive interactions among students during and after the summer school, fully in line with Edmondson's evidence (Edmondson, 1999, 2004). The benefits for students are also related to the diversity of educational backgrounds and the levels of education of participants shaping ideal conditions for learning from each other when preparing the final presentation. Therefore, our experience supports the argument of the professional and personal profits of networking (Sonnenberg, 1990). Fourth, it is the co-opetition among students especially when performing groupproject presentations. Thus, the experience of the EESS goes beyond Kolb's experiential learning style theory with its four-stage learning cycle: (1) having a 
concrete experience followed by (2) observation of and reflection on that experience which leads to (3) the formation of abstract concepts (analysis) and generalizations (conclusions) which are then (4) used to test a hypothesis in future situations, resulting in new experiences (Kolb 1984). In the EESS model, there are five core stages: (1) the pre-school exploration of empirical data on local entrepreneurship ecosystems, (2) a reflection on the obtained knowledge in a form of a poster to be presented, (3) the intensive study of relevant concepts and research methods in lectures and master-classes, (4) the exploration of related practices and institutions during onsite visits and practitioners' lectures, and (5) a collective testing of hypotheses and research questions in the form of a group-research project.

However, the experience of the EESS shows also some problems and limitations. First, it is the spatial fragmentation of teachers which is a serious constraint for a quick design and/or change of the learning community agenda before the active stage of preparation starts. Second, it is the geographical dispersion which negatively contributes to the creation of a student learning community, especially before having met other participants physically. Third, the EESS is an out of the curriculums volunteering activity for the organizers and teaching staff, thus their ability to actively engage in this summer school is restricted by their main workload. Therefore, the project is very much depending on the personal courage of the international team of the summer school-some partners dropping out can be explained by this fact. Forth, the financial model now is very much dependent on the goodwill of the participating universities' authorities, because the level of fees (currently, 250 EUR for participating universities' students and 500 EUR for third-party students) with the average number of participants equal to 30-35 persons does not cover all costs; in the meantime, to increase the fees could reduce the number of participants.

The potential avenues for development of the project are as follows. To make the EESS more attractive and to increase its impact, a broader participation of leading entrepreneurship research centers in the establishment and promotion of former EESS participants (for example, project internships, or scholarships for the very best of them) is needed. However, the EESS as a volunteer project of a small group of enthusiasts has still not gained such a strong reputation. To become fully recognized, the EESS should be evaluated by an international association, to receive a certificate of excellence. Unfortunately, there is no possibility for the assessment of educational modules which do not belong to any structured $\mathrm{MA}$ or $\mathrm{PhD}$ program.

\section{Authors' contributions Optional.}

Funding No funding from third parties.

Data availability Not applicable.

\section{Compliance with ethical standards}

Conflicts of interest No conflicts of interest. 
Code availability Not applicable.

\section{References}

Acs, Z. J., Autio, E., \& Szerb, L. (2014). National systems of entrepreneurship: Measurement issues and policy implications. Research Policy, 43(3), 473-494.

Arbaugh, J. B. (2000). Virtual classroom versus physical classroom: An exploratory study of class discussion patterns and student learning in an asynchronous internet-based MBA course. Journal of Management Education, 24(2), 213-234.

Bechard, J., \& Gregoire, D. (2005). Entrepreneurship education research re-visited: The case of higher education. Academy of Management Learning and Education, 4(1), 22-43.

Bennis, W. G., Berlew, D. E., Schein, E. H., \& Steele, F. I. (1973). Personal change through interpersonal relationships. In W. G. Bennis, D. E. Berlew, E. H. Schein, \& F. I. Steele (Eds.), Interpersonal Dynamics (pp. 237-267). Homewood, IL: Irwin-Dorsey.

Brower, H. H. (2003). On emulating classroom discussion in a distance-delivered OBHR course: Creating an on-line learning community. Academy of Management Learning \& Education, 2(1), 22-36.

Bryant, S. E. (2005). The impact of peer mentoring in organizational knowledge creation and sharing. Group and Organization Management, 30(3), 319-338.

Burt, R. S., \& Schott, T. (1985). Relation contents in multiple networks. Social Science Research, 14, 287-308.

Cheng, X., \& Wu, L.-Y. (2016). The affordances of teacher professional learning communities: A case study of a Chinese secondary school. Teaching and Teacher Education, 58, 54-67.

Chung, S., Singh, H., \& Lee, K. (2000). Complementarity, status similarity and social capital as drivers of alliance formation. Strategic Management Journal, 21(1), 1-22.

Clark, B. (1998). Creating entrepreneurial universities: Organizational pathways of transformation. Oxford: Pergamon.

Clark, L. J. (2001). Web-based teaching: A new educational paradigm. Intercom, 48, $20-23$.

Cox, A. (2005). What are communities of practice? A comparative review of four seminal works. Journal of Information Science, 31(6), 527-540.

Daniel, E. L. (2000). A review of time-shortened courses across disciplines. College Student Journal, 34(2), 298-308.

Daniel, A. D. (2016). Fostering an entrepreneurial mindset by using a design thinking approach in entrepreneurship education. Industry and Higher Education, 30(3), 215-223.

Dean, M. A., Shook, C. L., \& Payne, G. T. (2007). The past, present, and future of entrepreneurship research: Data analytic trends and training. Entrepreneurship Theory and Practice, 31(4), 601-618.

Debnath, S. C., Tandon, S., \& Pointer, L. V. (2007). Designing business school courses to promote student motivation: An application of the job characteristics model. Journal of Management Education, 31(6), 812-831.

Deci, E. L., \& Ryan, R. M. (1985). Intrinsic motivation and self determination of human behavior. New York: Plenum Press.

DeMarco, G. M. J., \& McCullick, B. A. (1997). Developing expertise in coaching: Learning from the legends. Journal of Physical Education, Recreation and Dance, 68(3), 37-41.

Doane, D. J., \& Pusser, B. (2005). Entrepreneurial organization at the academic core: The case of summer sessions. New Directions for Higher Education, 129, 43-54.

DuFour, R. (2004). What is a "professional learning community"? Educational Leadership, 61(8), 6-11.

Eastman, J. K., \& Swift, C. O. (2001). New horizons in distance education: The online learner-centered marketing class. Journal of Marketing Education, 23, 25-34.

Eby, L. T. (1997). Alternative forms of mentoring in changing organizational environments: A conceptual extension of the mentoring literature. Journal of Vocational Behavior, 51(1), 125-144.

Edmondson, A. (1999). Psychological safety and learning behavior in work teams. Administrative Science Quarterly, 44, 350-383.

Edmondson, A. (2004). Psychological safety, trust and learning: A group-level lens. In R. Kramer \& K. Cook (Eds.), Trust and distrust in organizations: Dilemmas and approaches (pp. 239-272). New York: Russell Sage. 
Ensher, E., Thomas, C., \& Murphy, S. E. (2001). Comparison of traditional, step-ahead, and peer mentoring on proteges' support, satisfaction, and perceptions of career success: A social exchange perspective. Journal of Business and Psychology, 15(3), 419-438.

Fayolle, A., Gailly, B., \& Lassas-Clerc, N. (2006). Assessing the impact of entrepreneurship education programmes: A new methodology. Journal of European Industrial Training, 30(9), 701-720.

Feld, S. L. (1981). The focused organization of social ties. American Journal of Sociology, 86(5), 1015-1035

Goffman, E. (1959). The Presentation of Self in Everyday Life. New York: Anchor Books.

Groen, A. J., Ulijn, J., \& Fayolle, A. (2006). Teaching diversity in technology entrepreneurship: Some experiences from The Netherlands and France. International Journal for Entrepreneurship and Small Business, 3(5), 517-537.

Gu, Q., Schweisfurth, M., \& Day, C. (2010). Learning and growing in a 'foreign' context: Intercultural experiences of international students. Compare: A Journal of Comparative and International Education, 40(1), 7-23.

Gustafsson, R., \& Ritala, P. (2018). Q\&A: Innovation and entrepreneurial ecosystem research: Where are we now and how do we move forward? Technology Innovation Management Review, 8(7), 52-57.

Higgins, D., Smith, K., \& Mirza, M. (2013). Entrepreneurial education: Reflexive approaches to entrepreneurial learning in practice. Journal of Entrepreneurship, 22(2), 135-160.

Howorth, C., Smith, S. M., \& Parkinson, C. (2012). Social learning and social entrepreneurship education. Academy of Management Learning \& Education, 11(3), 371-389.

Hwang, A., Kessler, E. H., \& Francesco, A. M. (2004). Student networking behavior, culture, and grade performance: An empirical study and pedagogical recommendations. Academy of Management Learning \& Education, 3(2), 139-150.

Kenworthy-U'Ren, A., Zlotkowski, E., \& Van de Ven, A. H. (2005). Toward a scholarship of engagement: A dialogue between Andy Van de Ven and Edward Zlotkowski. Academy of Management Learning \& Education, 4(3), 355-362.

Kirkman, B. L., Cordery, J. L., Mathieu, J., Rosen, B., \& Kukenberger, M. (2013). Global organizational communities of practice: The effects of nationality diversity, psychological safety, and media richness on community performance. Human Relations, 66(3), 333-362.

Kolb, D. A. (1984). Experiential learning: Experience as the source of learning and development (Vol. 1). Englewood Cliffs: Prentice-Hall.

Kolb, A. Y., \& Kolb, D. A. (2005). Learning styles and learning spaces: Enhancing experiential learning in higher education. Academy of Management Learning \& Education, 4(2), 193-212.

Kretovics, M. A., Crowe, A. R., \& Hyun, E. (2005). A study of faculty perceptions of summer compressed course teaching. Innovative Higher Education, 30, 37-51.

Kumpulainen, K., \& Rajala, A. (2017). Dialogic teaching and students' discursive identity negotiation in the learning of science. Learning and Instruction, 48(1), 23-31.

Leahey, E., \& Reikowsky, R. C. (2008). Research specialization and collaboration patterns in sociology. Social Studies of Science, 38(3), 425-440.

Lee, D. H. L., \& Shaari, I. (2012). Professional identity or best practices?: An exploration of the synergies between professional learning communities and communities of practices. Creative Education, $3(4), 457-460$.

Leeman, R., \& Whymark, J. (2001). Networking for knowledge and business improvement: A bumpy ride for networking? Management Services, 45(8), 14-17.

Lengnick-Hall, C. A., \& Sanders, M. M. (1997). Designing effective learning systems for management education: Student roles, requisite variety, and practicing what we teach. Academy of Management Journal, 40(6), 1334-1368.

Mercer, N., \& Howe, C. (2012). Explaining the dialogic processes of teaching and learning: The value and potential of sociocultural theory. Learning, Culture and Social Interaction, 1(1), 12-21.

Mudambi, R., Hannigan, T. J., \& Kline, W. (2012). Advancing science on the Knife's edge: Integration and specialization in management Ph.D. programs. The Academy of Management Perspectives, 26(3), 83-105.

Nabi, G., Liñán, F., Krueger, N., Fayolle, A., \& Walmsley, A. (2017). The impact of entrepreneurship education in higher education: A systematic review and research agenda. Academy of Management Learning \& Education, 16(2), 277-299.

Nielsen, S. L., \& Stovang, P. (2015). DesUni: University entrepreneurship education through design thinking. Education and Training, 57(8/9), 977-991. 
Olitsky, S. (2007). Facilitating identity formation, group membership, and learning in science classrooms: What can be learned from out-of-field teaching in an urban school? Science Education, 91(2), 201-221.

Pittaway, L., \& Cope, J. (2007). Simulating entrepreneurial learning: Integrating experiential and collaborative approaches to learning. Management Learning, 38(2), 211-233.

Pittaway, L., \& Edwards, C. (2012). Assessment: Examining practice in entrepreneurship education. Education and Training, 54(8/9), 778-800.

Poole, D. M. (2000). Student participation in a discussion-oriented online course: A case study. Journal of Research on Computing in Education, 33, 162-177.

Robinson, S., Neergaard, H., Tanggaard, L., \& Krueger, N. F. (2016). New horizons in entrepreneurship education: From teacher-led to student-centered learning. Education and Training, 58(7/8), 661-683.

Rothaermel, F. T., \& Boeker, W. (2008). Old technology meets new technology: Complementarities, similarities, and alliance formation. Strategic Management Journal, 29(1), 47-77.

Ruzek, E. A., Hafen, C. A., Allen, J. P., Gregory, A., Mikami, A. Y., \& Pianta, R. C. (2016). How teacher emotional support motivates students: The mediating roles of perceived peer relatedness, autonomy support, and competence. Learning and Instruction, 42, 95-103.

Sonnenberg, F. K. (1990). The professional (and personal) profits of networking. Training and Development Journal, 44, 55-60.

Sorenson, R. L., \& Milbrandt, J. M. (2015). A family affair-teaching families versus individuals: Insights Gained from 24 years of family business education. Academy of Management Learning \& Education, 14(3), 366-384.

Stanat, P., Becker, M., Baumert, J., Lüdtke, O., \& Eckhardt, A. G. (2012). Improving second language skills of immigrant students: A field trial study evaluating the effects of a summer learning program. Learning and Instruction, 22(3), 159-170.

Stoll, L., Bolam, R., McMahon, A., Wallace, M., \& Thomas, S. (2006). Professional learning communities: A review of the literature. Journal of Educational Change, 7(4), 221-258.

Terzian, M., Moore, K. A., \& Hamilton, K. (2009). Effective and Promising Summer Learning Programs and Approaches for Economically-Disadvantaged Children and Youth: A White Paper for the Wallace Foundation. New York: Wallace Foundation.

Vedder-Weiss, D., \& Fortus, D. (2012). Adolescents' declining motivation to learn science: A follow-up study. Journal of Research in Science Teaching, 49(9), 1057-1095.

Vescio, V., Ross, D., \& Adams, A. (2008). A review of research on the impact of professional learning communities on teaching practice and student learning. Teaching and Teacher Education, 24(1), 80-91.

Wang, L., \& Zajac, E. J. (2007). Alliance or acquisition? A dyadic perspective on interfirm resource combinations. Strategic Management Journal, 28(13), 1291-1317.

Welter, F. (2011). Contextualizing entrepreneurship-Conceptual challenges and ways forward. Entrepreneurship Theory and Practice, 35(1), 165-184.

Wenger, E. (1998). Communities of practice: Learning, meaning, and identity. Cambridge: Cambridge University Press.

Wenger, E., McDermott, R., \& Snyder, W. (2002a). A guide to managing knowledge: Cultivating communities of practice. Boston: Harvard Business School.

Wenger, E., McDermott, R., \& Snyder, W. M. (2002b). Cultivating communities of practice: A guide to managing knowledge. Boston: Harvard Business School Press.

Wiklund, J., Davidsson, P., Audretsch, D. B., \& Karlsson, C. (2011). The future of entrepreneurship research. Entrepreneurship Theory and Practice, 35(1), 1-9.

Zahra, S. A. (2007). Contextualizing theory building in entrepreneurship research. Journal of Business Venturing, 22(3), 443-452.

Publisher's Note Springer Nature remains neutral with regard to jurisdictional claims in published maps and institutional affiliations. 